\title{
Immobilization Optimization and Characterization of Immobilized Lipase from Lysinibacillus macroides FS1 for Biodiesel Production
}

\author{
Shilpa K. Jigajinni* and Bharati S. Meti \\ Department of Biotechnology, Basaveshwar Engineering College, S. Nijalingappa \\ Vidyanagar, Bagalkot 587103, Karnataka, India
}

*Corresponding author

\section{Keywords}

Lysinibacillus macroides FS1, Caalginate beads, Stability, Reusability, Fatty acid methyl ester

Article Info

Accepted:

12 March 2021

Available Online:

10 April 2021
Enzyme Immobilization favours operational stability, reuse, easy separation and enhanced stability than free enzyme. Lipase from Lysinibacillus macroides FS1 was entrapped into $\mathrm{Ca}$-alginate gel beads and effect of independent variables such as alginate concentration of $1-4 \%(\mathrm{w} / \mathrm{v})$ and $\mathrm{CaCl}_{2}$ concentration of $50-200 \mathrm{mM}$ on immobilization efficiency and activity were investigated. After optimization of immobilization conditions, maximum immobilization efficiencies of $69 \%$ and activity of immobilized lipase was $6.0 \mathrm{U} / \mathrm{ml}$ were recorded at optimum concentrations of $4 \%$ $(\mathrm{w} / \mathrm{v})$ sodium alginate and $200 \mathrm{mM} \mathrm{CaCl} 2$. The optimum temperature of both free and immobilized lipase was $45^{\circ} \mathrm{C}$ and optimum $\mathrm{pH}$ of free and immobilized lipase was $\mathrm{pH}$ 5 and 8 respectively. The lipase activity of $46 \%$ was recovered by immobilized lipase after 6 cycles of reusability. Stability studies revealed that immobilized lipase was more stable than free lipase at optimum $\mathrm{pH}(8)$ and temperature $\left(45^{\circ} \mathrm{C}\right)$ when incubated for $3 \mathrm{hr}$. Furthermore, the immobilized lipase showed enhanced stability to methanol than ethanol compared to free lipase. The biodiesel was produced by using immobilized lipase and it was confirmed by glycerol assay. These findings advise the efficient and sustainable use of the developed immobilized lipase as a biocatalyst for production of biodiesel.

\section{Introduction}

Lipases (triacylglycerol acyl hydrolases, E.C. 3.1.1.3) are hydrolyses group of enzyme which catalyses the hydrolysis triglycerides to glycerol and free fatty acids. In addition to that lipases are also able to catalyze a wide range of reactions like esterification, transesterification, inter-esterification, alcoholysis, acidolysis, and aminolysis with high substrate specificity. (Nawal et al., (2019), Yucel et al., (2013). Bacterial lipases have wide industrial applications like in food industry, textile, cosmetics, paper and pulp, pharmacy industry and also in synthesis of biodiesel. (Sirisha et al., 2010). The lipases being grouped as third largest class of commercialized enzymes owing to catalyze different reactions coupled 
with the high activity and stability in organic solvents (Adetunji and Olaniran., 2018). Microbial lipases are the most common significant source for biodiesel production due to their ease in production and purification steps(Kareem et al., 2020). The cost barrier of lipases remains a technological and economic constricts and this makes use of lipases for industrial scale less viable. As per studies carried out by Zavarise and Pinotti, 2019 suggests some alternatives like improvement in fermentation technologies, application of immobilization techniques and protein engineering for more effective lipase production. The way of making more effective lipase production process is modification in fermentation process and immobilization process for repeated reuse of enzymes.

Use of free lipases as industrial biocatalysts is not much advisable because of too costly for biotechnological applications along with drawbacks like soluble in homogenous catalysis system, product contamination, difficulty in recovery for reuse in the active form, unstable and inactivated by different environmental conditions. In order to make efficient enzyme utilization in bioprocesses and to abate the problems associated with free lipase immobilization has been recognized as an important strategy in enzyme technology as it enhances the enzyme activity, selectivity, stability and specificity and allow multiple reuses, and continuous operation of enzymatic processes. Furthermore, it improves process economy by lipase recycling and product purity (Helal et al., 2021, Adetunji and Olaniran, 2018). The term Immobilization of enzymes refers to physically confined or localized in a certain defined region of space with retention of their catalytic activities and which can be used repeatedly and continuously (Brena and Batista-Viera, 2006).

Immobilization can be done in numerous ways, adsorption, cross-linking or entrapment.
Entrapment is a physical restriction of enzymes within a confined space or network of support materials. Among the different techniques entrapment is one of the most efficient technique owing to its potential to improve enzyme stability, reduce biocatalyst leakage, and prevent chemical coupling of the enzyme with support material and create ideal microenvironment for the enzyme (Adetunji and Olaniran.,2018).This immobilization technique allows movement of both substrate and product through the matrix and is applicable to a wide range of carriers and lipases for biodiesel production (Kareem et al., 2020). Different organic (e.g. polymers) or inorganic support materials are used for entrapment among that sodium alginate is most widely used polymer due to its low cost, easy to use, mild gelling properties, biocompatibility, thermostability, effective particle size, availability and non toxicity(Ding et al.,2020). Hence lipase entrapment in calcium alginate beads has shown to be relatively safe and straightforward techniques so in this study lipase was immobilized using calcium alginate beads (Zusfahair et al., 2020). Energy is key factor of economic development of nation. The increasing demand of energy that results more dependence on fossil fuels (Tripathi et al., 2014). Currently world is facing scarcity of fossil fuels and large scale burning of fossil fuels leads to major environmental changes (Thangaraj et al., 2018). The need to find alternate for fossil fuels take turn to renewable energy sources which are more ecofriendly which are produced from biomass and can replace the existing energy sources. One of such renewable energy source is Biodiesel. Biodiesel is a mixture of Fatty Acid Methyl Esters (FAMEs) which is produced from renewable resources by transesterification process by the action of chemical catalyst or biocatalyst. To abate the issues related to chemical catalyst the use of biocatalyst was encouraged. Due to the high stability of 
enzymes as well as their convenient production, they are the best biocatalysts for producing biodiesel (Helal et al., 2021). Owing to the robust versatility and specificity of lipase to catalyze wide range of bioconversion reactions, the focus is required to explore indigenous bacterial strains with high catalytic efficiency and cost effective biocatalyst. This study therefore focused on optimization of lipase immobilization of Lysinibacillus macroides FS1 and characterise the immobilized lipases to investigate the potential application in biodiesel production.

\section{Materials and Methods}

\section{Lipase Production by submerged fermentation}

Lysinibacillus macroides FS1 was previously isolated from oil rich temple soil and identified using 16Sr DNA. The isolates were sub cultured routinely in the minimal media composed of $0.3 \%$ of yeast extract $0.5 \%$ $\mathrm{NaCl}, 0.5 \%$ peptone, $2 \%$ agar at $\mathrm{pH} 7$ and preserved in agar slants at $4 \mathrm{C}$ in the refrigerator (Sirisha et al., 2010).The lipase producing Lysinibacillus macroides FS1 was grown in optimized medium containing $3 \mathrm{gm}$ beef extract,3gm galactose,3gm ammonium chloride, $0.01 \mathrm{gm} \quad \mathrm{CaSO}_{4}, 0.05 \mathrm{gm} \quad \mathrm{KH}_{2} \mathrm{PO}_{4}$, $0.01 \mathrm{gm} \mathrm{MgSO}_{4} .7 \mathrm{H}_{2} \mathrm{O}, 1 \mathrm{gm}$ honge oil in $100 \mathrm{ml}$ distilled water and $\mathrm{pH}$ set to 7 . The flask were incubated at $37^{\circ} \mathrm{C}$ for $48 \mathrm{hr}$ at $120 \mathrm{rpm}$. The sample were collected after $48 \mathrm{hr}$ of incubation and centrifuged at $10000 \mathrm{rpm}$ for $30 \mathrm{~min}$ at $4 \stackrel{\mathrm{C}}{\circ}$ to collect supernatant as crude lipase source for lipase immobilization. (Bharathi et al., 2018, Babatunde and Sulaimon., 2017).

\section{Immobilization of lipase}

Varying concentrations (1\%-4\%, w/v) of sodium alginate were prepared by adding different quantities to $0.05 \mathrm{M}$ Tris HCL buffer $(\mathrm{pH} 7)$ and boiled for $5 \mathrm{~min}$ to form uniform slurry then cooled. The crude lipase was mixed with sodium alginate in equal proportion $(1: 1)$ by continuous stirring to obtain homogenous suspension. The enzymealginate mixture was added drop wise to cold $\mathrm{CaCl}_{2}$ solution $(50-200 \mathrm{mM})$ using a hypodermic syringe. The obtained beads were preserved for curing at $4{ }^{\circ} \mathrm{C}$ for $1 \mathrm{hr}$ (Adetunji and Olaniran, 2018). After curing beads (3 $\mathrm{mm}$ diameter) were collected from the solution by filtration and then washed with cold Tris- $\mathrm{HCl}$ buffer (0.05 M, pH 7) and distilled water to remove unbound enzyme. These beads were stored in distilled water at $4 \mathrm{C}$ till further use.

Lipase assay

Lipase activity of free and immobilized lipase was measured by Titrimetric method using olive oil as substrate. $1 \mathrm{ml} / 1 \mathrm{~g}$ of free and immobilized beads were added to reaction mixture containing $2 \mathrm{ml}$ of $0.05 \mathrm{M}$ phosphate buffer of $\mathrm{pH} 7.0$ and $1 \mathrm{ml}$ of olive oil, incubated at $37^{\circ} \mathrm{C}$ for $60 \mathrm{~min}$. The reaction was stopped by adding $1 \mathrm{ml}$ of acetone: ethanol solution in 1:1 ratio. The amounts of fatty acids were estimated by titrating with $0.05 \mathrm{M}$ $\mathrm{NaOH}$ in presence of phenolphthalein as a indicator until $\mathrm{pH}$ 10.5. Amount of $\mathrm{NaOH}$ consumed indicates the amount of fatty acids liberated. One unit of enzyme activity is defined as the amount of enzyme required to liberate $1 \mu \mathrm{mol}$ of equivalent fatty acid (Patel et al., 2018).Lipase activity was calculated by using following formula

Lipase Activity (U/ml)

$=\underline{\text { Vol. of alkali consumed } \mathrm{x} \text { Strength of alkali x } 1000}$ Vol. of sample $x$ Time in min

\section{Determination of Immobilization efficiency}

The immobilization efficiency is the percentage of bound enzyme activity observed in the immobilized beads. It was calculated 
using the equation that is described by Talekar and Chavare, 2012.

Immobilization efficiency \%

Activity of Immobilized

$=\frac{\text { Enzyme (IU) }}{\text { Activity of Free-wash water }} \times 100$
enzyme(FU) activity(RUS)

Characterization of free and immobilized lipase

Effect of temperature and $\mathrm{pH}$ on free and immobilized lipase activity

The effect of temperature on free and immobilized lipase activity was assessed by carrying out lipase assay at different temperatures ranging from 25 to $75^{\circ} \mathrm{C}$ at $\mathrm{pH} 7$.

The optimum $\mathrm{pH}$ of free and immobilized lipase activity was determined by carrying out lipase assay at optimum temperature in buffer solutions of $\mathrm{pH}$ values ranging from 5.0 to 10.0 .

The buffers used include $0.05 \mathrm{M}$ acetate buffer (pH 5.0), $0.05 \mathrm{M}$ phosphate buffer ( $\mathrm{pH} 6.0$ ), $0.05 \mathrm{M}$ Tris- $\mathrm{HCl}$ buffer (pH 7.0-9.0) and 0.05 M Glycine- $\mathrm{NaOH}$ buffer (pH 10.0). The lipase activities were calculated and the values were plotted against the respective temperature or $\mathrm{pH}$ (Adetunji and Olaniran, 2018).

\section{Stability of free and immobilized lipase to optimum temperature and $\mathrm{pH}$}

The temperature and $\mathrm{pH}$ stability of free and immobilized lipase was determined by keeping lipase in substrate solution at $45^{\circ} \mathrm{C}$ for a period of $3 \mathrm{hrs}$. Lipase activity was checked with a time interval of 30min (Hombalimath $e t$ al., 2020).
Stability of immobilized lipase to organic solvents

Stability to organic solvent is desirable feature in the process of esterification and transesterification, as these organic solvents may inhibit the lipase activity during tranesterification reaction. Biodiesel production can be greatly enhanced by evaluating stability of lipase to organic solvents. Hence to investigate stability of produced lipase to organic solvents, immobilized lipase was incubated with $1 \mathrm{ml}$ methanol and ethanol for 1 hour and residual lipase activity was assayed, as methanol and ethanol are the most commonly used organic solvents in biodiesel industry (Tripathi et al., 2014).

\section{Reusability potential}

The reusability of the immobilized lipase was evaluated by carrying out the lipase assay for six cycles at $45^{\circ} \mathrm{C}$ for $30 \mathrm{~min}$. After each cycle, the beads were separated by filtration using filter paper then washed with cold distilled water and Tris- $\mathrm{HCl}$ buffer $(\mathrm{pH} 8)$ and re-introduced into the reaction medium consisting of fresh substrate solution. Lipase activity was measured after every cycle under standard assay conditions. The residual lipase activity was calculated by taking the lipase activity of the freshly prepared beads in the first run as $100 \%$. (Adetunji and Olaniran, 2018 and Hombalimath et al., 2020).

\section{Biodiesel production}

Biodiesel was produced by using Pongamia seed oil. The tranesterification reaction was performed in $100 \mathrm{ml}$ conical flask containing $10 \mathrm{ml}$ Pongamia pinnata seed oil, $1.3 \mathrm{ml}$ methanol (1:3 ratio) and $5 \% \quad(0.5 \mathrm{~g})$ immobilized lipase and kept in shaking incubator at $37^{\circ} \mathrm{C}$ for $24 \mathrm{hr}$ with agitation speed of 120rpm. After $24 \mathrm{hr}$ reaction mixture 
were collected and filtered to remove immobilized beads, collected filtrate were added to separating funnel and left overnight for separation of biodiesel and glycerol (Vallari et al., 2015). The biodiesel layer was separated from the sediment layer of glycerol. The production of biodiesel was confirmed by glycerol assay. The glycerol assay was carried by following method:

\section{Reagents required}

Working Solution $=95 \%$ ethanol and distilled water in $1: 1$ ratio

Sodium periodate solution $=10 \mathrm{mM}$ sodium periodate in $1.6 \mathrm{M}$ acetic acid solution)

Acetyl acetone solution $=0.2 \mathrm{M}$ acetyl acetone was mixed with $1: 1$ solution of $1.6 \mathrm{M}$ acetic acid and 4M ammonium acetate.

Glycerol Assay: $0.5 \mathrm{ml}$ of sample was mixed with $1.5 \mathrm{ml}$ working solution and $1.2 \mathrm{ml}$ of sodium periodate was added followed by shaking for 30 seconds. After that $1.2 \mathrm{ml}$ of acetyl acetone was added and kept in hot water bath at $70^{\circ} \mathrm{C}$ for $1 \mathrm{~min}$ and immediately cooled in water. Formation of yellow colour indicates presence of glycerol. Absorbance was taken at $410 \mathrm{~nm}$. (Hombalimath et al., 2020).

\section{Results and Discussion}

\section{Lipase production and activity assay}

Production of lipase from Lysinibacillus macroides FS1 were carried in optimized medium as submerged fermentation process mentioned in methodology. The Media optimization was performed in previous studies and formulated optimised media for enhanced lipase activity. (Bharathi et al., 2018). The production of enzymes at industrial scale mainly uses the submerged fermentation (SmF) technology, as this method of fermentation process easy to monitor and to control (Melani et al., 2019). The use of submerged fermentation for lipase production using bacterial sp. gives satisfactory results studied by Vishwanatha et al., 2019.Culture supernatant were collected and lipase activity of $14.1 \mathrm{U} / \mathrm{ml}$ was assayed by titrimetric method as this is simplest method mentioned by Patel et al., 2018 and Sirisha et al., 2010.

\section{Optimization of Lipase Immobilization}

Immobilised lipase offers many advantages over free lipase in terms of reusability, operational stability and cost effective process. Entrapment is one of immobilization techniques in which enzymes are physically restricted within a confined space or network. Immobilization by using $\mathrm{Ca}$-alginate provides many benefits like its cost-effective process and environmentally friendly nature as per Qamar et al., 2020 and the concentrations of alginate and calcium chloride formed a key factor for enzyme immobilization Since cross linking between alginate and calcium chloride results in gelation (Adetunji and Olaniran, 2018). Therefore in this study the influence of sodium alginate and $\mathrm{CaCl}_{2}$ concentration on immobilization efficiency of lipase from Lysinibacillus macroides FS1 was investigated. Produced lipase was successfully immobilized and produced beads using various concentrations of sodium alginate and $\mathrm{CaCl}_{2}$ (Fig.1). As shown in the Table.1, the highest immobilization efficiency and yield of $76 \%$ and $38.2 \%$ was observed for $\mathrm{T} 7$ at $2 \%$ sodium alginate and $150 \mathrm{mM} \mathrm{CaCl}_{2}$ but the beads were too soft may be due to dilution of sodium alginate with equal amount of lipase in $1: 1$ ratio, hence it is difficult to be use in reaction mixture of biodiesel production and may be difficult for reuse of these beads therefore next highest immobilization efficiency and yield of $69 \%$ and $43 \%$ which 
was shown by $\mathrm{T} 12$ at $4 \%$ sodium alginate and $200 \mathrm{mM}$ calcium chloride were selected for further studies since these beads were physically stable. There was an increase in immobilization efficiency as the concentration of alginate increases from $1 \%$ to $4 \%(\mathrm{w} / \mathrm{v})$. The lower alginate concentration of $1 \%$ resulted in the formation of fragile beads which got disrupted easily and had larger pore sizes resulting in leakage of the enzyme from the beads thereby lowering enzyme activity (Malhotra and Basir, 2020 and Zusfahair et al., 2020). The concentration calcium chloride influences the stability and porosity of the beads. Maximum immobilization efficiency and yield (69\% \& 43\%) was recorded from beads prepared from $200 \mathrm{mM}$ calcium chloride. The similar finding were reported by Adetunji and Olaniran, 2018 in his studies.

\section{Characterization of Immobilized Lipase}

\section{Effect of Temperature and $\mathrm{pH}$ on activity of free and immobilized lipase}

The effect of temperature on both free and immobilized lipase was studied and it was found that maximum activity of both free and immobilized lipase was observed at $45^{\circ} \mathrm{C}$ as indicated in Fig. 2. Optimum temperature of $45^{\circ} \mathrm{C}$ for free and immobilised lipase has been reported. This may be because of the enzyme retain stable structure at this temperature. Beyond $45^{\circ} \mathrm{C}$ activity decreases up to $75^{\circ} \mathrm{C}$. The optimum temperature of free lipase was found to be quite similar with results obtained by Hombalimath et al.,2020 and Helal et al., 2021.Both enzyme preparations showed considerable activity in the broad $\mathrm{pH}$ range of 5.0-10.0, the results suggested that optimal $\mathrm{pH}$ of the immobilized lipase shifted to $\mathrm{pH} 8$ and free lipase at pH5(Fig.3). As per Fig. 3 it was observed that, there was much difference in optimum $\mathrm{pH}$ of free lipase and immobilized lipase. The optimum $\mathrm{pH}$ of free lipase found to be at $\mathrm{pH} 5$ and for immobilized lipase at
$\mathrm{pH} 8$, these findings revealed that at alkaline $\mathrm{pH}$ values, the immobilized lipase exhibited better activity than the free lipase, suggesting that the immobilization enhanced the tolerance of the lipase to alkaline conditions similarly reported by Ding et al., 2020.

\section{Stability of free and immobilised lipase to optimized temperature and $\mathrm{pH}$}

As indicated in Fig.4 both free and immobilized lipase showed the residual activity of $60 \%$ and $71 \%$ after $3 \mathrm{hrs}$ of incubation at $45^{\circ} \mathrm{C}$ respectively. It was observed that the thermal stability of immobilized lipase was more than that of free lipase. The greater thermal stability of immobilized lipase may be due to the protection provided by the support material, which stabilized the enzyme and maintained its bio catalytic activity. When comparing the activities of free and immobilized lipase, immobilization process considerably improves the thermal stability of enzymes, which states its importance for wide biotechnological applications. Such increased thermal stability of lipase entrapped in alginate beads has been reported by many studies (Kumar et al., 2014, Shafei and Allam, 2010, Adetunji and Olaniran, 2018, Hombalimath et al., 2020)

\section{Stability to organic solvents}

Enzymes are inactivated or denatured in presence of organic solvents which are the co substrates in transesterification reactions thereby limiting their use in some cases. Therefore Solvent stable lipases are one of the leading biocatalysts in non-aqueous environment due to their unique property of catalysing a wide variety of useful transformations (Ryan et al.,2019). The lipase from Lysinibacillus macroides FS1 demonstrated significant stability and activity in the presence of organic solvents. 
Table.1 Immobilization efficiency of lipase from Lysinibacillus macroides FS1 at different concentration of sodium alginate and calcium chloride.

\begin{tabular}{|c|c|c|c|c|}
\hline Test & $\begin{array}{c}\text { Sodium Alginate } \\
(\mathbf{\%})\end{array}$ & Calcium chloride(mM) & $\begin{array}{c}\text { Immobilization efficiency } \\
(\mathbf{\%})\end{array}$ & $\begin{array}{c}\text { Immobilization } \\
\text { yield(\%) }\end{array}$ \\
\hline T1 & 1 & 50 & 14.2 & 9.2 \\
\hline T2 & 1 & 100 & 31 & 13.4 \\
\hline T3 & 1 & 150 & 26 & 14.1 \\
\hline T4 & 1 & 200 & 33 & 18 \\
\hline T5 & 2 & 50 & 38 & 23.4 \\
\hline T6 & 2 & 100 & 50 & 39.2 \\
\hline T7 & $\mathbf{2}$ & $\mathbf{1 5 0}$ & $\mathbf{7 6}$ & 32 \\
\hline T8 & 2 & 200 & 61 & 26.2 \\
\hline T9 & 3 & 50 & 37 & 28.3 \\
\hline T10 & 3 & 100 & 48 & 35.4 \\
\hline T11 & 3 & 150 & 41.2 & 25 \\
\hline T12 & 3 & 200 & 52 & 27 \\
\hline T13 & 4 & 50 & 36.4 & 36.1 \\
\hline T14 & 4 & 100 & 39 & 43 \\
\hline T15 & 4 & 150 & 55 & $\mathbf{4 3}$ \\
\hline T16 & 4 & $\mathbf{2 0 0}$ & $\mathbf{6 9}$ & \\
\hline
\end{tabular}

Table.2 Stability of free and immobilized lipase to the organic solvents.

\begin{tabular}{|c|c|c|}
\hline SI.No. & $\begin{array}{c}\text { Organic } \\
\text { solvent }\end{array}$ & $\begin{array}{c}\text { Residual Activity of } \\
\text { immobilized lipase (\%) }\end{array}$ \\
\hline $\mathbf{1}$ & Control & 100 \\
\hline $\mathbf{2}$ & Methanol & 129 \\
\hline $\mathbf{3}$ & Ethanol & 57 \\
\hline
\end{tabular}

Fig.1 Immobilized beads of lipase from Lysinibacillus macroides FS1

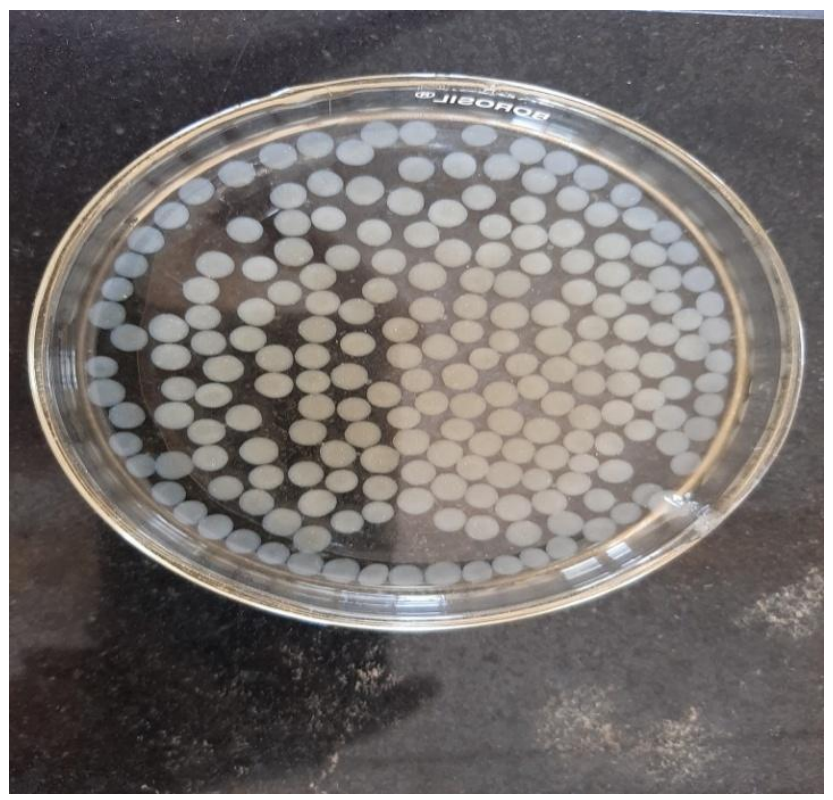


Fig.2 Effect of Temperature on activity of free lipase and immobilized lipase.

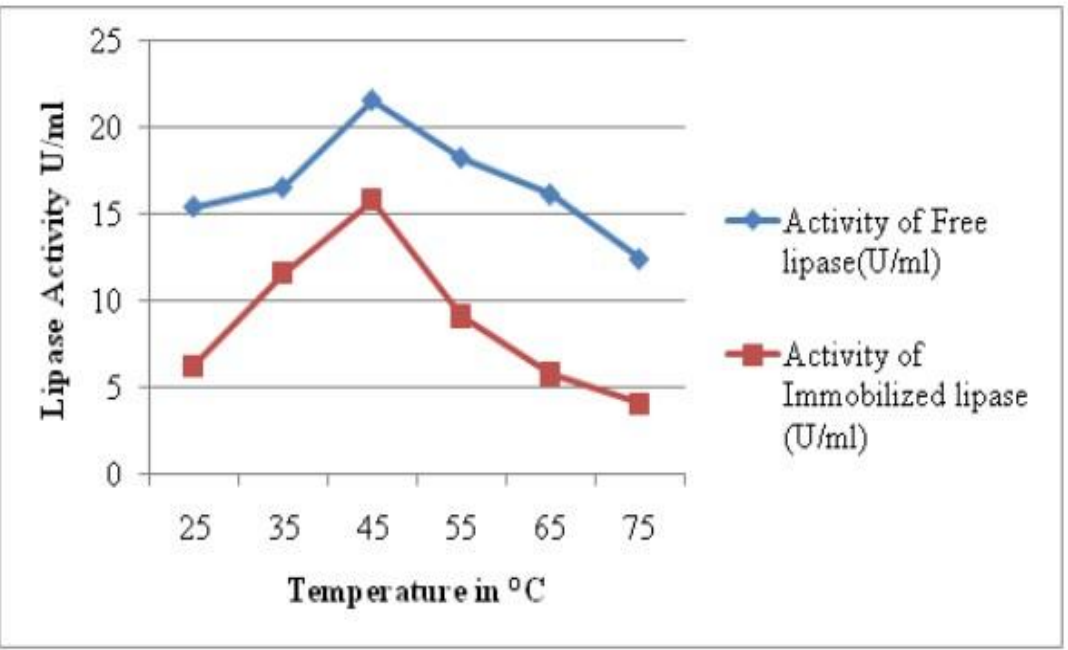

Fig.3 Effect of $\mathrm{pH}$ on activity of free lipase and immobilized lipase.

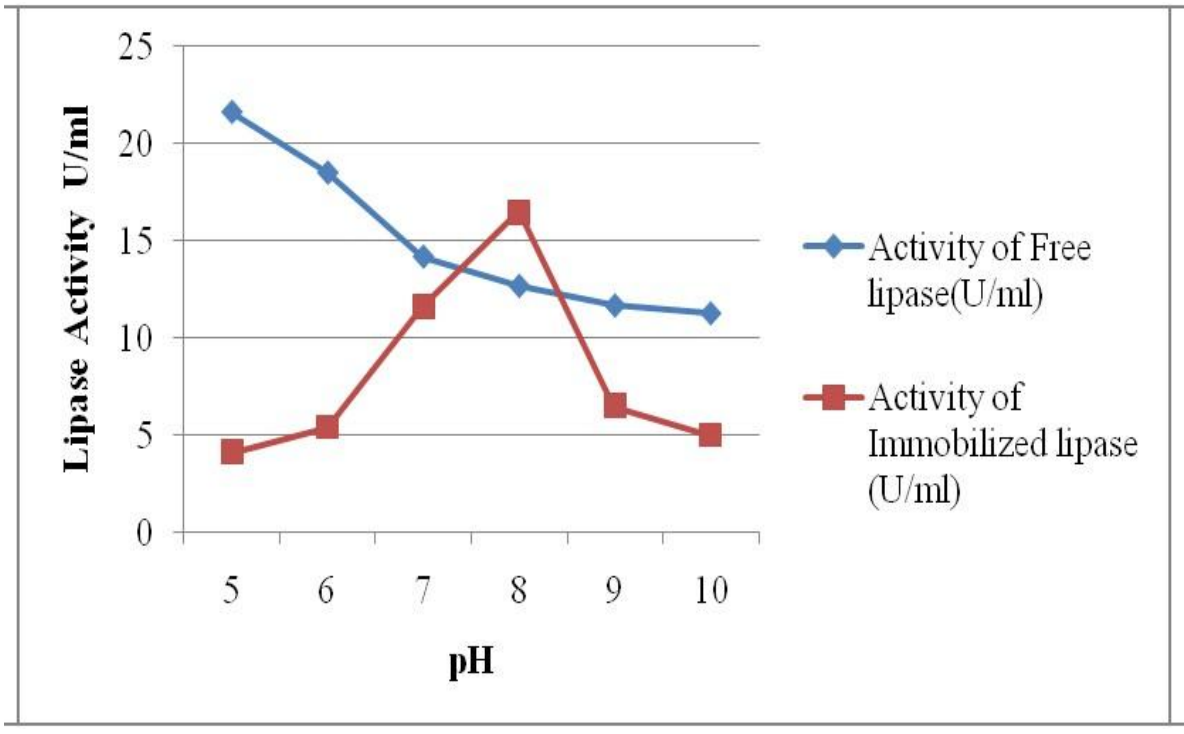


Fig.4 Stability of Immobilized lipase to optimum temperature and $\mathrm{pH}$.

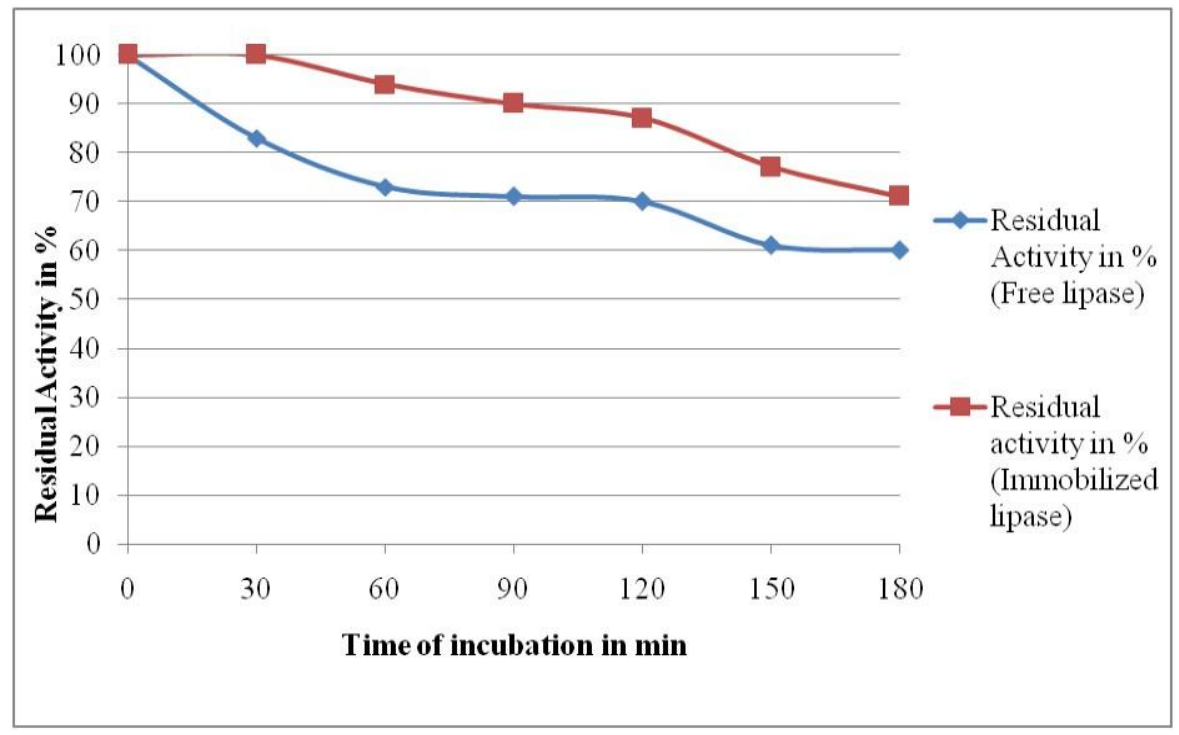

Fig.5 Reusability of Immobilized lipase

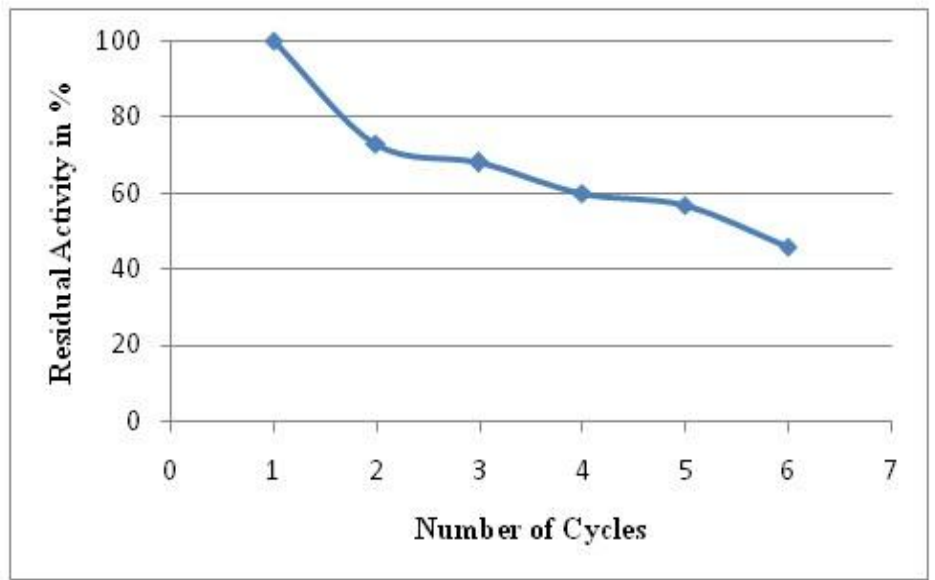




\section{Fig.6 Glycerol Assay}

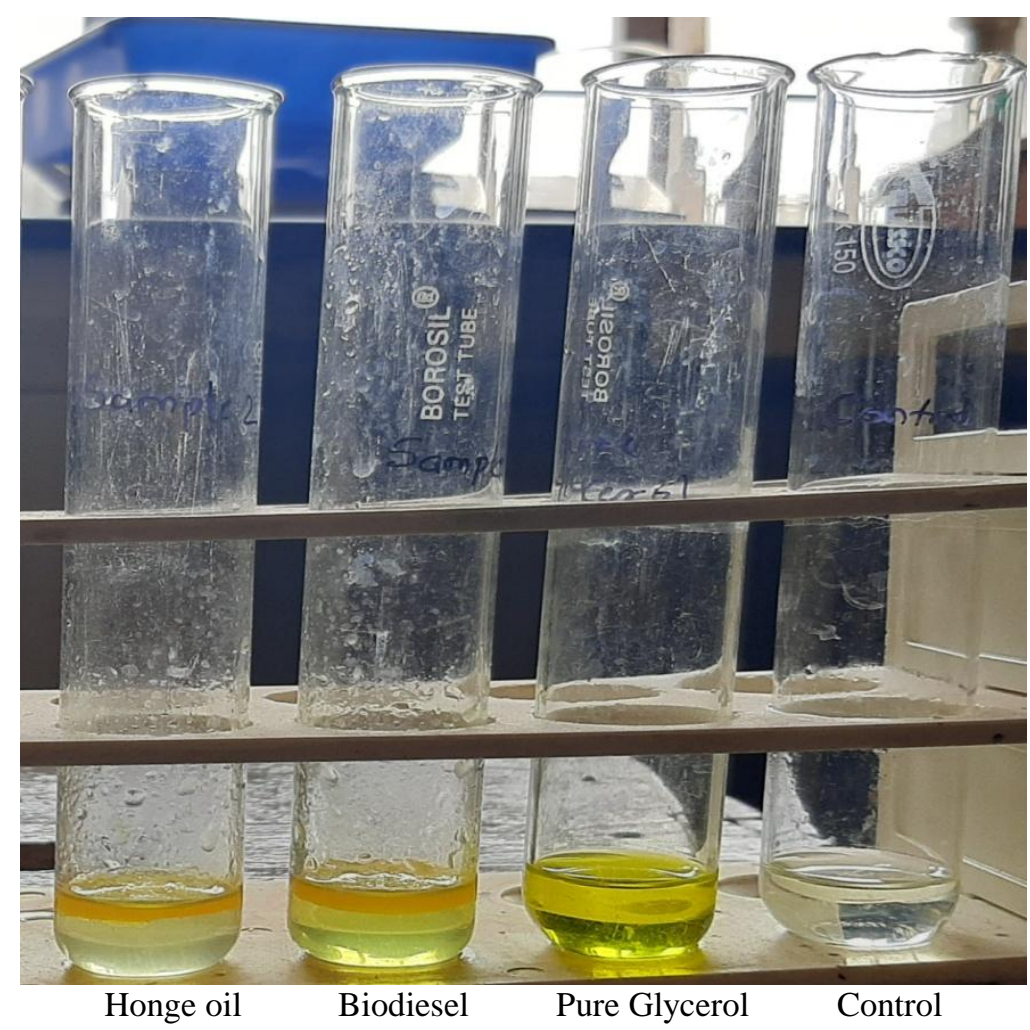

The stability of produced lipase to organic solvents was tested and results reveal that lipase was stable in presence of methanol than ethanol.

As per Table 2 it was noted that residual activity of immobilized lipase in presence of methanol and ethanol was $129 \%$ and $57 \%$ respectively, it indicates methanol has induces activity and ethanol inhibits the activity.

Ethanol affects negatively on lipase activity. Hence methanol is most suitable acyl acceptor for transesterification reaction in which lipase from Lysinibacillus macroides FS1 were used as biocatalyst (Table 2).

\section{Reusability of Immobilized Lipase}

The most important characteristic of immobilized enzyme is its stability and reusability for extended periods of time which can be reduce the operational cost for large scale applications. In the present study, lipase immobilized in alginate gel beads was assayed continuously for six cycles using olive oil as a substrate. The immobilized lipase retained the residual activity of $46 \%$ after six cycles as indicated in Fig.5. The residual activity of the immobilized lipase reduced with increase in the number of cycles this may be due to leakage of the lipase from the beads. Similar results have been reported by Zhang et al., 2013, Adetunji and Olaniran, 2018, Hombalimath et al., 2020 in which lipase immobilized in alginate beads was used for six cycles.

\section{Biodiesel Production}

Biodiesel production was assayed by using immobilized lipase as mentioned in methodology and analysed by glycerol assay. Biodiesel produced by the process of 
transesterification where Glycerol is byproduct of reaction. Biodiesel formation was confirmed by glycerol assay in which the sample is treated with sodium periodate, it reacts with free glycerol in the sample to generate formaldehyde. Reaction between this formaldehyde and acetyl acetone produces the yellow complex, 3, 5- diacetyl- 1,4dihydrolutidine. This yellow compound exhibits a maximum absorbance peak at 410 nm. As shown in Fig.6 the formation of yellow colour in pure glycerol and biodiesel sample indicates the presence of glycerol which shows that immobilized lipase can catalyse the tranesterification process to produce the biodiesel. (Hombalimath et al., 2020)

In the present study, calcium alginate gel beads were prepared and used as support material for immobilization of lipase from Lysinibacillus macroides FS1 via entrapment method. Maximum immobilization efficiency and lipase activity was recorded at optimal conditions of $4 \%(\mathrm{w} / \mathrm{v})$ and $200 \mathrm{mM}$ for sodium alginate and calcium chloride, respectively.

Both free and immobilized lipase had maximum activity at optimum temperature $\left(45^{\circ} \mathrm{C}\right)$ and $\mathrm{pH}(8)$. Conversely, the entrapped lipase exhibited improved $\mathrm{pH}$ and temperature stability over optimized conditions for $3 \mathrm{hr}$. Furthermore, the immobilized lipase showed better reusability for up to six consecutive cycles and able to convert the Pongamia oil to biodiesel, suggesting the efficient and costeffectiveness of the developed immobilized biocatalyst for biodiesel production.

\section{Acknowledgment}

We thank Department of Biotechnology Basaveshwar Engineering College(A), Bagalkot for providing facilities to carry out experiments.

\section{References}

Adetunji, A. I \& Olaniran, A. O. 2018. Immobilization and characterization of lipase from an indigenous Bacillus aryabhattai SE3-PB isolated from lipidrich wastewater. Preparative Biochemistry and Biotechnology.48(10): 898-905.

Amini, Z., Ilham, Z., Hwai Chyuan Ong, Mazaheri, H., Wei-Hsin Chen. 2017. State of the art and prospective of lipasecatalyzed transesterification reaction for biodiesel production. Energy Conversion and Management. 141: 339-353.

Babatunde, A. and Sulaimon, A. 2017. Optimization and Lipase Production of Lysinibacillus sphaericus in Domestic Oil Rich Waste Water. Biotechnology Journal International.19(4):1-12.

Bharathi,D., Rajalakshmi, G., Komathi, S. 2018.Optimization and production of lipase enzyme from bacterial strains isolated from petrol spilled soil. Journal of king saud universityscience.31(4):898-901.

Bhushan, I., Parshad, R., Qazi, G N. 2008. Immobilization of lipase by entrapment in ca alginate beads. J. Bioact. Compatible Polym. 23: 552-562.

Bonine, B. M., Polizelli, P. P., BonillaRodriguez, G. O. 2014.Immobilization of a Plant Lipase from Pachira aquatica in Alginate and Alginate/PVA Beads. Enzyme Res.1-7.

Brena, B., González-Pombo, P., Batista-Viera, F.2006. Immobilization of Enzymes: A Literature Survey. Immobilization of Enzymes and Cells.15-31.

Coorevits, A., Dinsdale, A. E., Heyrman, J., Schumann, P., Van Landschoot, A., Logan, N. A., and De Vos, P. 2012. Lysinibacillus macroides sp. nov., nom. rev. Int J Syst Evol Microbiol.62:11211127. 
Ding, S., Zhu, J., Wang, Y., Bin Wu. and Zhao, Z. 2020. Immobilization of the extracellular recombinant Lucky9 xylanase from Bacillus subtilis enhances activity at high temperature and pH.FEBS Open Bio 10. 2733-2739.

Elavarasi, N., Karthick Venkatesh P. 2012. Production and characterisation of biodiesel using Pongamia oil by immobilized Rhizopus oryzae. Advanced Biotech.11

Golani, M., Hajela, K. and Pandey G. P. 2016. Screening, Identification, Characterization and Production of Bacterial Lipase from Oil Spilled Soil. International journal of current microbiology and applied sciences. 5(3):745-763.

Helal, S. E., Abdelhady, H. M., Abou-Taleb, K. A., Hassan, M. G. and Ame.M.M.2021. Lipase from Rhizopus oryzae R1: in-depth characterization, immobilization, and evaluation in biodiesel production. $\mathrm{J}$ Genet Eng Biotechnol. 19(1):1-13.

Hombalimath, V. S., Desai, S. V., Sharanappa, A. 2020. Characterization Of Lipase Immobilized On Chitosan Magnetic Micro-Particles For Economic Biodiesel Production. International journal of scientific \& technology research. 9(3): 5111-5116.

Kareem, S. O., Falokun, E. I., Balogun, S. A., Oluwaseyi A. A. and Omeike, S. O. 2020. Improved biodiesel from palm oil using lipase immobilized calcium alginate and Irvingia gabonensis matrices. Beni-Suef Univ J Basic Appl Sci. 9(59):1-8.

Kayath Aimé Christian,Vouidibio Mbozo Alain Brice, Mokémiabeka Saturnin Nicaise, Kaya-Ongoto Moïse Doria, Nguimbi Etienne. 2020. The Genus Lysinibacillus: Versatile Phenotype and Promising Future.International Journal of
Science and Research (IJSR). 8(1):12381242.

Kumar, A., Parihar, S., Batra, N. 2012. Enrichment, isolation and optimization of lipase-producing Staphylococcus sp. from oil mill waste Oil cake. J. Experimental Sci.38: 26-30.

Kumar, S., Yadav, R. K., Negi, S. A.2014. Comparative Study of Immobilized Lipase Produced from Penicillium chrosogenum SNP5 on Two Different Anionic Carriers for Its $\mathrm{pH}$ and Thermostability. Indian J. Biotechnol.13:301-305.

Kumar, D., Kumar, L., Nagar, S., Raina, C., Parshad, R., Gupta, V. K. 2012. Screening, isolation and production of lipase/esterase producing Bacillus sp. Strain DVL2 and its potential evaluation in esterification and resolution reactions. Archives of applied science research. 4(4):1763-1770.

Malhotra,I. \& Basir,S.F.2020. Immobilization of invertase in calcium alginate and calcium alginate-kappa-carrageenan beads and its application in bioethanol production. Preparative biochemistry \& biotechnology.50(5): 494-503.

Maytham Ayuob Alhamdani and Hanna Jaffer jabbar Alkabbi. 2016.Isolation and identification of lipase producing bacteria from oil-contaminated soil. Journal of Biology, Agriculture and Healthcare.6(20): 2224-3208.

Meher, L. C., Naik, S. N. and Das, L. M. 2004.Methanolysis of Pongamia pinnata for production of biodiesel. Journal of Scientific and industrial Research.63: 913-918.

Melani, N. B., Tambourgi, E. B. and Silveira, E. 2019. Lipases: From Production to Applications. Separation \& Purification Reviews.00: 1-16.

Nawal, G., Irfan, M., Ashfaq, S. and Shakir, H. A. 2019. An overview of bacterial 
lipases and their enormous applications. Punjab Univ. J. Zool.34(1): 61-71.

Patel P., Desai, B.2018. Isolation, identification and production of lipase producing bacteria from oil contaminated soil. BMR Microbiology. 4 (1): 1-7.

Qamar, S. A., Asgher, M., Bilal, M. 2020. Immobilization of Alkaline Protease From Bacillus brevis Using Ca-Alginate Entrapment Strategy for Improved Catalytic Stability, Silver Recovery, and Dehairing Potentialities. Catalysis Letters.150:3572-3583.

Ryan, B., Priyanka, P., Kinsella, G. and Henehan, G. 2019. Isolation, purification and characterization of a novel solvent stable lipase from Pseudomonas reinekei. Protein Expression and Purification. 153:121-130.

Selva Mohan, T., Palavesam, A. and Immanvel, G. 2008.Isolation and characterization of lipase producing Bacillus strains from oil mill waste. African Journal of Biotechnology. 7(15):2728-2735.

Shafei, M. S. and Allam, R. F. 2010. Production and Immobilization of Partially Purified Lipase from Penicillium chrosogenum. Malay. J. Microbiol.6:196-202.

Sirisha, E., Rajasekar and Lakshmi Narasu M. 2010.Isolation and optimization of lipase producing bacteria from oil contaminated soils. Advances in Biological Research. 4(5):249-252.

Srivastava, A. and Prasad, R. 2000.Triglycerides based diesel fuel. Renewable and sustainable Energy reviews. 4(2):111-133.

Talekar, S. and Chavare, S. 2012. Optimization of immobilization of $\alpha$ amylase in alginate gel and its comparative biochemical studies with free $\alpha$-amylase. Recent Research in Science and Technology. 4(2): 01-05.
Thangaraj, B., Solomon, P. R., Bagavathi, M., Srinivasan, R. and Lin Lin. 2018. Catalysis in biodiesel productiona review. Clean Energy. Vol. XX, No. $X X: 1-22$.

Tripathi, R., Singh, J., Bharti, R. K., Thakur, I. S.2014. Isolation, purification and characterizartion of lipase from Microbacterium sp. and its application in biodiesel production. Energy Procedia.54:518-529.

Vallari, R., Chourasia, A. S., Gawas, A. S., Menon, P. M., Shinde.2015. Production of Biodiesel by Enzymatic Transesterification using Immobilized Lipase. International Journal of Engineering Research and General Science.3 (3):1238-1246.

Vishwanatha, T., Patil, S. J., Siddalingeshwar, K. G. and Hiremath, L. 2019.Isolation and Screening of Lipase Producing Microbes from Oil Contaminated Soil. Advances in Bioplastics.7-13.

Wadia, T. and Jain, S. K. 2017.Isolation, Screening and Identification of Lipase Producing Fungi from Oil Contaminated Soil Of Shani Mandir Ujjain. International journal of current microbiology and applied sciences.6(7): 1872-1878.

Yücel, S., Terzioğlu, P. and Özçimen, D. 2012. Lipase Applications in biodiesel Production Intech Open.

Zavarise, J. P., Pinotti., L. M. 2019.Progress in the production of fungal lipases by submerged fermentation. International Journal of Advanced Engineering Research and Science. 6 (12):367 -373.

Zhang, S., Shang, W., Yang, X., Zhang, S., Zhang, X., Chen, J. 2013. Immobilization of Lipase Using Alginate Hydrogel Beads and Enzymatic Evaluation in Hydrolysis of $p$ Nitrophenol Butyrate. Bull. Korean Soc. 34:2741-2745. 
Zusfahair, D. R., Kartika, N. D., Kurniasih, M., Nofiani, R., Faton, A.2020.Improved reuse and affinity of enzyme using immobilized amylase on alginate matrix.
Journal of Physics: Conference Series. 1494012028 .

\section{How to cite this article:}

Shilpa K. Jigajinni and Bharati S. Meti. 2021. Immobilization Optimization and Characterization of Immobilized Lipase from Lysinibacillus macroides FS1 for Biodiesel Production. Int.J.Curr.Microbiol.App.Sci. 10(04): 232-245. doi: https://doi.org/10.20546/ijcmas.2021.1004.023 